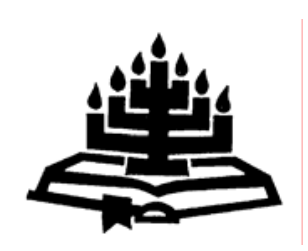

\title{
Die messiaanse aard van psalms: hoe dit 'n Nuwe-Testamentiese lees, vertaling en omdigting van die psalms raak
}

\author{
J.L. Helberg (emeritus)
}

Skool vir Bybelwetenskappe en Bybeltale

Potchefstroomkampus

Noordwes-Universiteit

POTCHEFSTROOM

E-pos: jaapjlh@absamail.co.za

\begin{abstract}
The messianic character of the psalms: how it affects a New Testament reading, translation and re-versification of the psalms
\end{abstract}

The 2001 re-versification of the psalms as well as the 1983 translation in Afrikaans is rejected by some, because the messiah is not rendered in capital letters. This article views the matter from the perspective of Psalm 1 and 2 as an introduction which characterises the whole psalter as messianic. This article explores what this means. The relation between Psalm 2 (re kingship) and Psalm 1 (re the Law/Word of Yahweh) is investigated in able to view the "messianic" concept in its real perspective. The same applies to the relation Old TestamentNew Testament and expectation-fulfilment. The regenerative character of the fulfilment in Christ as well as its implication for one's inclination towards one's neighbour and how it affects that of the psalmists is explored. The conclusion of the article is that to render the messiah in capital letters in the psalms is to bypass the regenerartive fulfilment by Christ and to ignore the implication thereof regarding enemies.

\section{Opsomming}

Die messiaanse aard van psalms: hoe dit 'n Nuwe-

Testamentiese lees, vertaling en omdigting van die psalms raak

Die nuwe omdigting van die psalms in Afrikaans en ook die Bybelvertaling van 1983 word deur sommige mense afgewys omdat die messias in die messiaanse tekste nie met hoofletters 
weergegee is nie. Hierdie artikel bekyk die saak vanuit Psalm 1 en 2 as 'n inleiding wat die hele psalmbundel as messiaans stempel. Die verhouding tussen Psalm 2 (oor koningskap) en Psalm 1 (oor die Wet/Woord van Jahwe) word bekyk om die begrip "messiaans" in perspektief te stel. Dieselfde geld die verhouding $\mathrm{Ou}$ Testament-Nuwe Testament en verwagtingvervulling. Verder word gekyk na die ingrypende betekenis van die vervulling deur Christus en die implikasie daarvan vir 'n mens se houding teenoor vyande en hoe dit die psalmdigters se houding raak. Die bevinding is: om die messias in die psalms met hoofletters weer te gee, is om bo-oor die ingrypende vervulling deur Christus te spring en die implikasie in verband met die vyande te ignoreer.

\section{Inleiding: problematiek}

Die nuwe omdigting van die psalms in Afrikaans en die 1983Bybelvertaling word deur sommige mense afgewys, omdat die messias in die messiaanse tekste nie met hoofletters vertaal en omgedig is om direk na Christus te verwys nie. (Die Hebreeuse teks het geen aparte hoofetters nie.) In Psalm 2:6-7 moet "koning" en "seun" dus met hoofletters wees en in Psalm 110:1 en 3 moet "my koning" en "u" dus "my Here" en "U" wees. Volgens D'Assonville jnr., Kayayan en Schulze (2004:33) is Christus daarmee uit die psalms weggedig en is Hy self in gedrang, asook "die hart van God se openbaring en van die evangelie; die eenheid van die verbond en van die Ou en Nuwe Testament, die gesag van die Skrif en van God self". Meijer (2002:9) beweer dat Christus in die psalms deur sy Gees sy eie psalms sing. Die eintlike problematiek is egter dieper en wyer as dit waarop die kritiek in enkele sogenaamde messiaanse tekste konsentreer en moet benader word teen die agtergrond van al die psalms en van die Ou Testament as 'n geheel.

Van Rooy $(2005: 622-623,628)$ toon hierdie aspek duidelik aan en weerlê die kritiek grondig (vgl. verder Van Rooy 2004:3-5, 10-11 se bespreking van D'Assonville, 2002a; D'Assonville, 2002b; 2004 en van onder andere Davis, 2000:173 en Paul, 1987:202). Van Rooy (2004:12) stel dat die 2001-omdigting nie 'n streep trek deur die moontlikheid om die lyn na Christus toe te volg nie, maar die omdigting begin met dit wat die psalm in die oorspronklike konteks wou sê. In eksegese en prediking sal die lyn na Christus toe, en die Nuwe Testament se hantering van die psalm aan die orde moet kom, aldus Van Rooy, maar dit is nie die taak van die psalmberyming (of 'n Bybelvertaling) om al daardie sake in die beryming in te werk nie. Van Rooy (2004:11-12) wys daarop dat die 
kritiek uit Psalm 110:1 se 1933-/1953-vertaling aanhaal asof dit die Massoretiese teks is; asof daar Adonai staan. In werklikheid staan daar adoni, iemand van hoër rang, soos in 1 Samuel 24:7, 9.

In die Griekse vertaling van die Ou Testament - en dus ook in die Nuwe-Testamentiese aanhalings van die vers - word dieselfde woord gebruik vir drie woorde wat in die 1933-/1953vertaling op drie maniere weergegee word: HERE, Here en my heer. Psalm 110 kan wel verstaan word as dat dit in die oorspronklike konteks gedui het op die koning uit die huis van Dawid, en (weer) kan 'n mens maklik van daar af die lyn volg na Jesus Christus toe, soos wat die Nuwe Testament inderdaad doen (Van Rooy, 2004:11-12).

Anders as wat genoemde kritiek beweer, aanvaar Van Rooy (2005:620-621) dus die messiaanse verkondiging in die Ou Testament en hy lewer kritiek op Gerstenberger (2002:283) en Preuss (1996:305) as voorbeelde van persone wat dit nie doen nie. Ook Verhoef (2004:36-39) weerlê die kritiek dat die 2001psalmomdigting en die 1983-Bybelvertaling Christus wegvertaal. Christus is wel in die tekste aanwesig, maar op die vlak van die spits van die piramide, in die sin van 'n Christosentriese ontsluiting van die betrokke tekste.

In hierdie artikel wil ek aandui dat Psalm 1 en 2, synde 'n inleiding tot die hele psalmbundel, verdere lig op die problematiek werp, deurdat die hele bundel as messiaans gestempel word, maar dan in Ou-Testamentiese sin. As dit nie so benader word nie, en die verskil tussen die Ou Testament en die Nuwe Testament nie ernstig geneem word nie, kan Christus self en die implikasie van sy koms juis in gedrang kom.

Die verhouding tussen Psalm 2 (oor koningskap) en Psalm 1 (oor die Wet/Woord van Jahwe) is belangrik om die begrip messiaans in perspektief te sien. (Vgl. Helberg, 2005:678 vir Tora in Ps. 1 in die engere betekenis van Wet sowel as die wyere betekenis van Woord.) Verder is die verhouding van die Ou Testament en die Nuwe Testament tot mekaar ook belangrik, asook dit wat onder verwagting en onder vervulling verstaan behoort te word. Daarom sal aandag gegee word aan wat messiaans in Ou-Testamentiese en in Nuwe-Testamentiese sin onderskeidelik inhou. Dieselfde geld van die aard van die Ou Testament as geheel (voorlopig) en van die Nuwe Testament as geheel (vervulling). Sommige benaderings ónder-vra en beperk die messiaanse gedeeltes in die psalms. Die benadering wat die nuwe omdigting en die nuwe vertaling verwerp, 
óór-vra hierdie gedeeltes en rek hulle bedoeling en reikwydte te ver. Albei die benaderings maak te min erns met dit wat in die benaming vervat is wat vroeg reeds deur die kerk gebruik is, naamlik Ou Testament en Nuwe Testament.

\section{Die Ou Testament se oopheid na die toekoms toe}

Die Ou Testament is oop na die toekoms toe in dié sin dat dit self meer in die vooruitsig stel as wat die werklikheid in die OuTestamentiese tyd bied aangaande Israel se verhouding met die nasies en met God en aangaande 'n mens se verhouding met God. By die roeping van Abraham sluit God 'n verbond met Israel en sluit die ander nasies daarvan uit. Tegelykertyd word egter in die vooruitsig gestel dat al die nasies van die aarde in Abraham geseën sal word (Gen. 12:1-3). Jeremia 31:31-34 stel selfs 'n nuwe bedeling in die vooruitsig: 'n nuwe verhouding wat tussen God en Israel sal geld, naamlik 'n nuwe verbond. Daarin sal die verhouding tussen God en Israel nog net so innig wees soos vroeër ("Ek sal hulle God wees - hulle sal my volk wees"). Die verskil is egter dat God sy Wet in hulle harte sal skrywe. God sal self die gehoorsaamheid aan die Wet bewerkstellig. Die Wet sal nie meer wees asof dit van buite kom, waar dit op kliptablette geskryf is, soos tydens die wetgewing by Sinai nie. God sal die verandering deur sy Gees bewerkstellig (Eseg. 36:27). Israel se geskiedenis, so-ook die geskiedenis van die mensdom in geheel, het gewys dat in plaas daarvan dat die Wet verlossing bewerk, dit 'n obstruksie vorm tussen Israel en God, asook tussen die mens in die algemeen en God. In plaas van redding deur die Woord is daar vernietiging (Jes. 40:6-8). Die oorsaak hiervan is die sonde wat begaan is (Helberg, s.a.:220). In die boek Jesaja word 'n verandering in die vooruitsig gestel, deurdat God die obstruksie sal wegneem deur, ondanks die obstruksie, self na sy volk toe te kom (Jes. 40:2, 8b, 9-11).

Sommige navorsers meen dat daar nie in die Ou Testament sprake is van messiaanse oopheid nie, met ander woorde van 'n koning wat meer is as bloot die Judese koning of konings nie (Toombs, 1971:261; Gerstenberger, 2002:283). So 'n geslote benadering stuit egter op die oopheid wat die Ou Testament as 'n geheel vertoon. Ander sien weer baie messiaanse gedeeltes, soms selfs te veel, op die klank af. Van Rooy (2004:5-10) bespreek die verskeidenheid benaderings van die begrip messiaans, van die messiaanse interpretasie by die vroeë kerk, die kerkvaders en Calvyn en die verskille wat selfs tussen geesgenote oor die begrip messiaans bestaan, soos tussen die evangelicals. W. Kaiser en Tremper 
Longman 111 sê byvoorbeeld dat messiaanse psalms in 'n eng eksklusiewe sin nie bestaan nie en dat Jesus die fokuspunt van die Bybel as geheel is. Verder wys Van Rooy (2004:11) op die baie psalms wat in die Nuwe Testament aan die messias verbind word en wat ook nie in die ouer vertaling en beryming direk-Messiaans weergegee word nie.

Snyman (2002a:7-17; 2002b:1-2,4) meen dat geeneen van die "sleutels" om die verhouding tussen Ou en Nuwe Testament te verklaar heeltemal bevredig nie; dat die Ou Testament nie tot sy reg kom om 'n eie boodskap te verkondig nie en eintlik gedegradeer word as voorlopig Woord van God, wat eers in die Nuwe Testament aan die woord kom. Eers wanneer dit saam met die Nuwe Testament gelees word, is die Ou Testament volledig Woord van God.

My benadering in hierdie artikel is dat die Ou Testament oop is na die toekoms in dié sin dat dit 'n beperktheid het, maar dat dit tegelyk 'n verwagting oor iemand wat menslike vermoëns te bowe gaan in die vooruitsig stel. Die beperktheid of voorlopigheid van die $\mathrm{Ou}$ Testament is nie 'n degradering van sy boodskap nie, maar hang saam met sy openbaringshistoriese plek voor die ingrypende gebeurtenis van die koms van Christus en die ingrypende implikasie daarvan.

Helberg (1983:10-46) behandel die geskiedenis van die verklaring van die Ou Testament en die gesag van die Ou Testament (vgl. ook Bright, 1967:58-109 en Van Rooy, 2005:622-624 oor die verskillende waarderings van die Ou Testament). Helberg (1983:98-99) stel die verhouding tussen die $\mathrm{Ou}$ Testament en die Nuwe Testament soos volg: binne die kanon wat vir ons deur Jesus Christus en die vroeë kerk oorgelewer is, beklee die Ou Testament 'n plek as Ou Testament (Verbond) teenoor die Nuwe Testament (Verbond). Dit hou in dat die Ou Testament in die lig van die Nuwe Testament verklaar moet word. Tog het die Ou Testament ook betekenis in homself. In die lig van die Nuwe Testament het die Ou Testament nie 'n ander betekenis nie, maar 'n veranderde betekenis, 'n "opgestane" betekenis (vgl. ook hier onder). Bright (1967:201) sê:

We have to hear and accept the Old Testament as the Old that it is, inseperably related to the New, yet not the same as the New ... The New Testament, while unbreakably linked with the Old, announces the intrusion of something New, therewith, the end of the Old. It affirms the fulfillment of Israel's hope - and 
pronounces radical judgment on that hope as generally held. It announces the fulfillment of the law - and the abrogation of the way of the law.

Die Ou Testament moet dus in dié sin eskatologies gelees word. Dit moet homself wees en tog bokant homself uitstyg. Dit moet dieselfde bly en tog iets nuuts wees.

Childs (1986:241-242) sê:

Indeed, one of the important tasks of Old Testament theology is closely to describe the profile of the Old Testament witness without fusing it with that of the New Testament ... The description of the coming ruler varies greatly from prophet to prophet, and is consistently joined to contingent historical events in the life of Israel ... Increasingly the righteous king of the line of David took on roles which transcended human qualities (Isa. 9:6) ... Still, the point must be emphasized that no one profile of the messiah emeged in the Old Testament, nor did it ever become the single dominant feature of Israel's faith. It belongs to the Christian confession when all the disparate parts within the old covenant suddenly assumed a new and unified meaning within God's promise.

Die Ou Testament moet dus enersyds self aan die woord kom met wat hy vir die mense in die skrywers se eie tyd wou sê, sonder om Nuwe-Testamentiese gedagtes in te lees. Daarna moet die betekenis van die betrokke gedeelte na die Nuwe Testament toe deurgetrek word. Ou en Nuwe Testament vorm saam 'n eenheid en moet aanvullend tot mekaar gelees word. Die Ou Verbond het plek gemaak vir die Nuwe. Die Ou Testament het egter nie verval nie, maar is deur die koms van Jesus Christus in sy diepste kern geraak en moet nou by daardie lig gelees word (vgl. Matt. 5:17). Bright (1967:147) benadruk tereg dat die teologie (ek sou sê "openbaring") in die Ou en die Nuwe Testament dieselfde is.

Die Ou Testament is nie 'n onvoltooide Testament of Verbond nie, nie 'n halwe Woord van God of 'n halwe getuienis oor God se heerskappy en oor verlossing nie, maar 'n volledige verkondiging van God se heerskappy en sy gemeenskap met die mens asook van die roeping van die mens. Die Ou Testament moet in sy geheel deur die Nuwe Testament belig word en so-ook die Nuwe Testament deur die Ou Testament (ook in verband met vyande). Die Ou Testament bly geldig deur dood en opstanding heen, saam met Jesus Christus, die Woord wat mens geword het, en die Nuwe Testament ontstaan uit dié opstanding van die mensgeworde Woord 
(vir meer besonderhede vgl. Helberg, 1983:89 oor "Die Woord deur die dood heen saam met die volk en vir die volk"). Christus maak die Ou Testament die Oú Testament en die Nuwe Testament die Núwe Testament. Hy maak die twee tegelykertyd 'n eenheid. Die Ou Testament bly homself, maar word tog oud deur bokant homself uit te wys. Daarom is hy dan juis tegelykertyd nuut deur die lig wat op hom en vanuit hom val deur die dood en opstanding van Jesus Christus.

In die Nuwe Testament word verskeie psalms met Christus in verband gebring en as messiaans beskou (vgl. byvoorbeeld oor Ps. 110: Matt. 21:9, 39, 42; 22:43-45; 26:64; Hand. 2:34; 7:55; Rom. 8:34; Ef. 1:20; Hebr. 1:13; 5:6; 7:11-25; 8:1; 10:12,13). Die Nuwe Testament kyk egter na die psalms en ander OuTestamentiese gedeeltes vanuit die vervulling in Christus en het 'n eie manier om met hierdie Ou-Testamentiese gedeeltes om te gaan. Dit is duidelik uit die aanhaling van die "God-by-ons"-gedeelte (Jes. 7:14) dat dit op Christus dui (Matt. 1:22, 23), maar wat in Jesaja op 'n kind in Jesaja se tyd betrekking het, en nie eens op 'n koning nie. Verklaring, vertaling en omdigting kan nie dieselfde kortpad na Christus toe volg nie. Hieroor later meer. Aangesien die messiaanse gedeeltes op 'n noue manier aan die koningskap verbind is, word vervolgens na die koning gekyk.

\section{Die plek van die koning in die psalms}

Die koning het 'n belangrike rol in Israel gespeel, veral van die tyd van Dawid af tot met die ballingskap (vgl. Ps. 2; 18; 45; 72; 89; 101; $110 ; 132 ; 144: 1-11)$. Die koningskap is veral verbind met die verbond wat Jahwe met Dawid gesluit het (2 Sam. 7). Daarkragtens is alle konings uit die geslag van Dawid konings van Jahwe (Ps. 2:6; 18:51; 89:4-5; 132:11-12; vgl. Kraus, 1972:LXVIII-LXIX). Sommige indiwiduele bidders het die konvensionele formulerings van die koninklike voorreg in hulle gebede en liedere opgeneem (vgl. Ps. 3). In die inleidende psalms, Psalm 1 en 2, staan die gelowige se indiwiduele verhouding met God voorop, nie die koning s'n nie. Die verbondsbeloftes van God aan Dawid geld vir die hele volk, so het God in Jesaja 55:3 beloof.

Israel het groot verwagtings van die koning gekoester; hy spreek reg namens God (Ps. 72:1; 122:5). Geregtigheid, voorspoed en vrede word verwag van hoe hy regeer (Ps. 72:3-11; 132:15). Hy beklee 'n bemiddelingsposisie (Kraus, 1972:LXX). Die koning is feilbaar, maar in die beoordeling oor hom val die klem op die belofte van God aan Dawid. Hierdie belofte is aan die posisie van die koning verbind, en 
die oplossing word gesoek in God se eie heerskappy. Hierdie benadering verskil grondig van dié van die ander nasies en word verbind aan 'n heerlikheid wat nog verborge is en wat kragtens God se beloftes enige tyd kan deurbreek (vgl. ook Weiser, 1959:78).

Verskillende navorsers oor die psalms neem aan dat die redakteurs die psalms veral in die na-ballingskapse tyd in 'n bepaalde raamwerk georden het. Hierin speel die Tora sowel as die koning belangrike rolle (vgl. Zenger, 2000:432 oor Psalm 119). Wilson (1992:133, 134) wys op sy beurt op die besondere rol wat die betekenis van die koning in die strukturering deur die redakteurs speel. Een van die raamwerke het ontstaan deur die plasing van die koningpsalms aan die "some" van die eerste hoofsegment (Ps. 2; 72 ; 89) en wat uitgebrei is na die tweede hoofsegment deur die plasing van ' $n$ addisionele koningspsalm aan die einde van Boek 5 (Ps. 144). Die raam wat so gevorm is, fokus op die Dawidiese verbond. Wilson $(1992: 140,141)$ sê verder dat volgens die sentrale psalms van Boek 4 (Ps. 93; 95-99) die koningskap van Jahwe, anders as menslike vorste, vir altyd regeer. Die ballingskap is dus nie die gevolg van die swakheid van Jahwe nie, maar van Israel se sonde en ongehoorsaamheid (Ps. 90:7-8; 106:6-42). God wat in antwoord op Israel se pleidooi in Psalm 89 kom en in Psalm 93-99 as koning oor die aarde troon, is lofprysing waardig. Daarmee sluit die psalmbundel af. (Vgl. ook McCann, 1993:105 oor die ballingskap, verstrooiing en hoop; 'n hoop wat besonderlik beliggaam is in die openingspsalms van elke boek, Ps. 2; 42-43; 73; en Brueggemann, 1991:83 oor die kwessie van reg en geregtigheid wat op 'n noue manier met die koningskap verbind is.)

Die aard van die messiaanse koning en sy koninkryk is ten nouste met dié van Israel en hulle koning verbind, maar verskil ook daarvan. Dit is eintlik God wat deur sy gesalfde koning regeer. Dikwels word God se heerskappy deur die psalms besing, selfs sonder dat die koning ter sprake kom, soos in Psalm 92 (vgl. v. 9); 93 (vgl. v. 1, 4); 94 (vgl. v. 1-2); 95 (vgl. v. 3); 96 (vgl. v. 10, 13); 97 (vgl. v. 1,); 98 (vgl. v. 1, 1-3, 6, 9); 99 (vgl. v. 1, 4); 102 (vgl. v. 13); 104 (vgl. v. 1). God se koningskap word veral gesien as 'n wêreldwye regering en veral een wat reg en geregtigheid laat seëvier (vgl. byvoorbeeld Ps. 93:15; 96:10,13; 97:1; 98:9; 99:4; 102:23).

Die geskiedenis van Israel wys dat menslike koningskap nie die koninkryk van God na reg kan afskadu nie. In Dawid se regering word iets gesien van die oorwinnende aard van die koninkryk, maar nie van die vredeskarakter van die koninkryk nie. Daarom word hy 
nie toegelaat om die tempel vir Jahwe te bou nie (2 Sam. 7), maar Salomo wel. Salomo skiet op sy beurt te kort aan die innige verhouding met God (1 Kon. 11). Die Dawidmodel skiet ook tekort in die dienskarakter wat in die dienaarliedere in Jesaja 40-55 voorkom, veral in die lydende dienaar van die Here (Jes. 53). Verder skiet Dawid as vader tekort, so geheel anders as God die Vader (Gen. 5:1-3), byvoorbeeld in die Paradysgeskiedenis (Gen. 2-3) en selfs toe Hy sy Seun skynbaar verlaat het (vgl. Christus se kruiswoorde hieroor).

Die aanduiding van Jahwe as koning kom betreklik min in die $\mathrm{Ou}$ Testament voor. Jahwe is 13 keer die subjek van mlk qal, daarvan sewe keer in die malak-Jahwe-psalms en verwante stukke (Kraus, 1972:915). Dat God weinig kere koning genoem word, hang blykbaar saam met die gevaar van verkeerde assosiasies van koningskap en gode by die ander nasies (vgl. Helberg, s.a.:133). Hier in die psalms is dit anders, moontlik omdat die mislukking van die aardse konings die fokus na God as Koning laat verskuif het.

Die tema "openbaring en wetgewing by Sinai" speel in die psalms 'n opvallend geringe rol (Kraus, 1972:LXXII). Tog is die kern van die saak teenwoordig en die inleidende Psalms 1 en 2 ken selfs 'n allesbeheersende plek aan die Tora toe. Kratz (1996:2-3) oorspeel die rol van Dawid as hy, in aansluiting by die Midrasj, die titel "Die Tora van Dawid" vir die psalms voorstel.

Uit die voorgaande blyk dat die koning 'n belangrike rol in Israel se lewe en toekomsverwagtings gespeel het, maar tog leemtes vertoon het en dat die verwagtings veel meer gevestig is op God se beloftes en trou wat verder strek as die koningskap en die aard daarvan. Die Wet/Woord beklee 'n beheersende posisie.

\section{Psalm 1 en 2 as inleidende psalms en hulle verbandlegging tussen koning/messias en Wet/Woord}

Die inleidende psalms, veral Psalm 2, dui op die messiaanse karakter van die psalmbundel. Mitchell $(1997: 88,89)$ sê selfs die psalms is "arranged in terms of an eschatologically oriented editorial agenda". Die Ou Testament gee wel nie 'n uitgewerkte leerstuk oor die messias nie, maar veel meer 'n verskeidenheid voorstellings. Die tekening is dikwels misterievol. Ons moet dit nie te teologieswetenskaplik wil afbaken en inperk nie, maar die Ou Testament se vryheid handhaaf en in verwondering daarvoor staan. Vriezen (1966:477) wys byvoorbeeld daarop dat die woord messias (gesalfde) nêrens in die Ou Testament in verband met die 
verlosserfiguur voorkom nie. Hy word op verskillende maniere aangedui, maar nêrens as messias nie; die koningsnaam word ook nie direk op hom toegepas nie. In aansluiting by Gemser (1949:103) wys Vriezen (1966:497) verder daarop dat die swaartepunt van die Ou-Testamentiese heilsverwagting nie in die messias lê nie, maar in die paroesia, die nabye koms van Jahwe.

Die koning, veral verteenwoordig deur Dawid, het 'n belangrike plek in die psalms, maar dit is die koning gemeet aan die Tora, as die eintlike regerende faktor (vgl. veral Ps. 72). Die meeste psalms wat deur die opskrifte aan Dawid toegeskryf word, handel nie oor sy amptelike koningskap nie, maar oor aspekte van sy persoonlike lewe, insluitende sy swakheid, lyding en sonde (Childs, 1979:521). Die uitgangspunt vir die inleiding tot die psalms is dus nie die menskoning nie, maar die koningsmens, die mens wat deur die Tora beheers of regeer word. Dit kom veral duidelik na vore in Psalm 1:2 waarin die mens se omgang met die Tora voor die gedeelte oor die koning (Ps. 2) gestel word. Ook by die skepping gaan dit nie om 'n koning nie, maar om 'n gewone mens, die mens as beeld van God, verteenwoordiger van God, in 'n noue persoonlike verhouding met God, soos 'n Vader en kind (Gen. 1:26; 5:1-3).

Psalm 2 handel oor die opstand van die nasies en hulle konings teen Jahwe en die regeerder wat deur Hom gesalf is, bedoelende die koning van die verbondsvolk Israel. Deur hierdie koning sal Jahwe meer doen as wat van 'n gewone koning verwag kan word. Jahwe sal die hele aarde as besitting aan hom gee en hom alle volke laat verpletter (Ps. 2:8, 9). Hierdie koning staan in 'n besondere noue verhouding met Jahwe, maar hy is nie 'n godmens, soos by Israel se tydgenote nie. Hy is net deur Jahwe as sy seun aangeneem (Ps. 2:7; Kraus, 1972:19; Ridderbos, 1955:24), soos wat Israel ook 'n aangenome seun van God is (Eks. 4:22). Hier word dus enersyds iets meer as 'n gewone koning se moontlike optrede in die vooruitsig gestel, maar andersyds word die koning van Israel gesien as beperk tot 'n gewone mens. Voorop in Psalm 1 en 2, as twee-eenheid en inleiding tot die psalmbundel, staan die Wet/Woord van Jahwe waaraan die koning onderwerp is (Ps. 1).

Gesien teen hierdie agtergrond is Psalm 2 messiaans, maar nog in Ou-Testamentiese sin, dit wil sê sonder dat die messias in sy vervullende hoedanigheid herkenbaar is. Duidelik is wel dat God deur 'n koninklike persoon, wat meer as 'n gewone menslike koning is, op wonderdadige manier sy vyand gaan oorwin. Psalm 2 is nie op die messias gesentreer nie, maar ten volle op God self. Die klem val op wat Jahwe met en deur sy gesalfde doen, nie op die gesalfde 
self nie. Die psalm eindig dan ook met 'n oproep aan die regeerders van die aarde om Jahwe met ontsag te dien en by Hom skuiling te soek.

Deur die koning te sien as 'n aangenome kind, nie 'n godmenslike wese nie, en deur die plasing van Psalm 2 nie voorop in die psalmbundels nie, maar ná Psalm 1 waarin die Wet/Woord van Jahwe beheersend is, word ook die gesalfde koning ten volle onder die heerskappy van die Wet/Woord geplaas. Psalm 1 sê dat 'n mens die Wet/Woord van Jahwe dag en nag moet oordink, dit wil sê jou denke, trouens jou hele lewe, geheel en al deur die Wet/Woord moet laat bepaal. Daarmee word die Wet/Woord, nie die koning nie, aangedui as die bepalende faktor in die verwagtings oor Jahwe se regering en die verbondsvolk se verwagtings vir die toekoms.

Anders gestel: die verhouding van Psalm 1 en 2 en hulle plasing as 'n inleiding vooraan in die psalms, dui aan dat die psalms as geheel in die vooruitsig stel dat Jahwe die nasies gaan onderwerp deur middel van sy gesalfde, die koning (Ps. 2:6). Daarvan is die koning van Israel/Juda se tyd 'n teken of simbool, maar nie die volle vergestalting nie. Die fokus moet vir Israel nie gerig wees op die heerskappy soos dit in die gewone koning na vore kom nie, maar op die heerskappy van die Wet/Woord oor die lewe van 'n mens, die koning ingesluit. In die messias, die gesalfde koning van die toekoms, is daar dus kontinuïteit sowel as diskontinuïteit met die gewone koning.

Die oopheid van die Ou Testament, soos gesien in Psalm 1 en 2, impliseer 'n moontlike universele koninkryk waarin die vyande van God en van Israel, verteenwoordig deur die koning as die aangenome seun van God, deur bekering 'n plek kry. Psalm 2:11, 12 roep die regeerders van die aarde op om Jahwe met ontsag te dien, anders sal hulle omkom deur sy toorn. Tog volg daar dat dit goed gaan met elkeen wat by Hom skuiling soek.

Die messiaanse aard van Psalm 2 beteken dat hy vir die ballingskapse en/of na-ballingskapse volk van God in hulle moeilike, onderhorige omstandighede 'n verwagting gee van 'n heerskappy/ koninkryk van God wat alle hindernisse te bowe sal kom. Dit beteken egter nie dat hierdie verwagting direk op Jesus Christus, soos $\mathrm{Hy}$ in die Nuwe-Testamentiese bedeling geken word, dui nie. Die messiaanse aard van Psalm 2 gee aan die volk van Jahwe 'n vaste grond vir hoop. Maar hierdie hoop en verwagting moet gerig wees op die omgaan met die Wet/Woord van Jahwe en oorgawe daaraan. Die verwagting moet nie gerig wees op 'n Godmenslike 
koningsmag, soos by Israel se bure nie. Die fokus is op God se magtige optrede en wat God "vandag" doen (Ps. 2:7); nie op 'n mitiese of mitologiese manier nie, maar histories.

Hierdie "vandags"-optrede of historiese optrede van God gaan die menslike optrede of prestasie te bowe en het 'n wêreldwye uitwerking, soos hierbo aangedui is. Dit gaan bo-oor die grense wat Dawid of die Dawidiese konings kon bereik en wek 'n verwagting op vir een of ander optrede van God in die toekoms wat die menslike optrede te bowe sal gaan.

In selfs die voortreflikste menslike konings haper daar iets om 'n ware weergawe of simbool van God se koninkryk te wees. Selfs Dawid, simbool van Gods heerskappy, en man na God se hart, is byvoorbeeld nie toegelaat om die tempel te bou nie, omdat hy te veel bloed vergiet het (onder andere met sy oorloë). Die verwagtings bly in die Ou Testament dus steeds op God self gerig om 'n oplossing te bewerk op 'n manier wat aan Hom alleen bekend is. Die klem in die Ou Testament lê nie op die messias nie, maar op God se koms na sy volk toe. Jesaja 40:6-8 raak hierdie saak aan deur te verkondig dat God self die onoplosbare spanning tussen God se Woord en Israel, asook die mens in die algemeen, sal oorbrug deur self te kom (Jes. 40:9-11; vgl. Helberg, s.a.:219-220). Israel leef dus in die Ou-Testamentiese bedeling uit die verwagting op God se ingryping tot redding, wat meer is as 'n gewone reddende optrede. Dit staan in 'n noue verband met 'n koning, maar tog neem die Wet/Woord, die persoonlike wil van Jahwe, die beheersende plek in.

\section{Die Ou Testament en die psalms se voorlopige, beperkte en tegelyk korrektiewe aard}

Die Ou Testament is nasionaal beperk: net Israel is die uitverkore volk van God. Die nasies word oor die algemeen as vyande geag al is daar vooruitsigte dat al die nasies uiteindelik ingesluit sal word (Gen. 12:1-3; Jes. 19:25; 42:6; 49:6; vgl. ook Rut, Jona en veral Ps. 87). Hierdie beperktheid is dus tydelik en voorlopig van aard, maar is wel daar. Israel kon hierdie tydelike en voorlopige, funksionele aard nie verstaan nie, maar het die situasie van hulle bevoorregting verabsoluteer.

Met Psalm 1 en 2 as inleiding tot die psalmbundel word hierdie nasionale beperktheid in beginsel deurbreek: die klem val op die keuse wat die indiwiduele gelowige moet maak om sy lewe deur die Wet/Woord/wil van Jahwe te laat beheers. Daarmee word vyandskap oor 'n morele boeg gegooi. Tog bly die psalms nog sterk 
deur die probleem van vyandskap beheers en word Jahwe gevra om die vyande te straf en selfs te vernietig. Dit geld dikwels die eie volksgenote en persoonlike vyande (vgl. byvoorbeeld Ps. 3-7). Die liefdesgebod (Lev. 19:18) vind nie in die psalmdigters se gebede weerklank nie. Die psalmdigters bly daarmee worstel dat geregtigheid moet geskied. Geregtigheid word trouens deur die Wet/Woord van die Here vereis.

'n Houding teenoor die vyand soos Christus vereis, vra dat daar eers 'n ander perspektief geopen moet word, naamlik die perspektief op hoe God deur Christus geregtigheid beoefen: nie deur 'n koning met militêre of ander uiterlike mag en oorwinning nie, maar deur 'n heel ander soort koning. Hy het eerder die teenoorgestelde van 'n koning geblyk te wees, eerder 'n verloorder, Een wat oorwinning en geregtigheid bewerk deur "die onsin van die kruis" (1 Kor. 1:18-25). Christus moes eers histories, werklik kom. Eers nadat Hy Homself ter wille van sy vyande laat doodmaak het, het sy eis om 'n mens se vyande lief te hê, sinvol geword en is die soeke na geregtigheid, so tiperend van die psalmdigters, ook daarin beantwoord. Eers deur die historiese werklikheid van die koms van die Gees van die opgestane Christus, kon die mens se oë en hart daarvoor oopgemaak word. lets daarvan kom wel na vore in die lydende dienaar in Jesaja 53 (vgl. Helberg, s.a.:220-221), maar dit ontbreek in die psalms.

Hier is die benaming Ou Testament en Nuwe Testament en wat daarin vervat is, ter sake. Vir die Ou-Testamentiese messiaanse gedeeltes om werklik in hulle volle diepte verstaan te word, sou daar eers iets nuuts moes gebeur, so ingrypend nuut dat die bestaande daardeur oud sou word. Die afwesigheid van uitgesproke liefde vir die vyand in die psalms, ook in Psalm 2 (en Ps. 110) wat messiaans is, wys dat daar nie in die psalms Nuwe-Testamentiese gedagtes ingelees moet word nie. Die saad daarvoor is wel reeds in die psalms (en in die Ou Testament as geheel) gesaai deur die aanduiding van iets meer as die huidige situasie en koning, ook deur die moontlikheid van skuiling by God vir die konings van die aarde in Psalm 2, maar dat dit behels het wat in Christus aangebreek het, was nog nie duidelik nie. Daarvoor moes daar eers 'n ingrypende deurbraak kom - 'n deurbraak van versoening. Die Woord moes deurbreek om mens te word.

Soos hierbo gesien, is die verwagings in die Ou Testament nie aan 'n enkele gedagtelyn, die koningsfunksie, verbind nie, maar veral aan hoe God deur sy Wet/Woord werk of sal werk. Die verbinding in Christus van die gedagtelyne oor God se verlossingswerk, sou die koningskap in 'n heeltemal nuwe lig plaas, anders as die 
messiaanse koning, gesien na sy tekening as regeerder in Psalm 2. Die Messias sou veel meer die aard van 'n kneg of dienaar hê.

Ballard (1999:94) wys tereg op die ooreenkoms met ou NabyeOosterse beskouings, maar ook op die verskil: Jahwe as die afwesige Goddelike Stryder (Warrior) en Jahwe as 'n Goddelike vredemaker is kensketsende gebruike van die Goddelike Strydermotief in die psalms. Die harde antagonisme teenoor vyande in die psalms moet gelees word teen die agtergrond van die soeke na geregtigheid en binne die wyere konteks van vermanings in die Tora om goed te wees vir die vyande (Lev. 19:17, 18; Eks. 23:4-5; Spr. 24:17; 28:17; vgl. oor laasgenoemde oorweging Sheppard, 1991: 81). Jesus se leringe oor goed wees teenoor vyande sluit aan by die Joodse geskrifte en is nie 'n "Christelike" korrektief op die "Ou" Testament nie.

Die Ou Testament het self wel 'n bepaalde korrektief op die leser (vgl. Helberg, s.a.:3 oor die korrektiewe Woord van God). Psalm 1 en 2 as inleidende psalms laat die psalms begin met 'n korreksie op die benadering van die mens as enkeling, sowel as van die nasies en van die koningskap. Die mens moet nie die pad van verleiding volg om, soos onregverdiges doen, sy eie kop te volg en tog daarmee skyn weg te kom in die werklikheid van die lewe nie (Ps. 1:1). Hy moet hom onder die Wet/Woord/wil van Jahwe stel (Ps. 1:2). Die nasies moet afsien van hulle opstandige houding teenoor Jahwe (Ps. 2:1-3, 10-12). Die koningskap moet nie soos by die nasies gesien word as iets goddeliks, soos Israel ook maar soms in die praktyk gedoen het nie. Hierdie korrektiewe aard van Psalm 1 en 2 is hermeneuties baie belangrik: menslike benadering, hetsy soos dié van die nasies, hetsy soos dié van Israel en die konings, moet plek maak vir goddelike perspektief in die Tora.

Ook Psalm 3, die eerste psalm na die inleidende psalms, bevat 'n sekere regstelling. Die psalm begin deur oor die baie vyande te praat. Die opskrif koppel die psalm aan Dawid toe Hy vir sy seun Absalom gevlug het. Die opstand van Absalom teen Dawid kan nie losgemaak word van Dawid se sonde met Batseba nie. Implisiet word hier dus daarop gewys dat die een wat aan die woord is, self ook nie heeltemal vry uitgaan nie.

Ook Psalm 139 is regstellend teenoor die digter self. Hy uiter kras woorde oor die vyande, maar eindig dan: "Deurgrond my, o God ... sien tog my onrus raak. Kyk of ek nie op die verkeerde pad is nie en lei my op die beproefde pad." In Psalm 143 stel die digter hom sterk teenoor die vyande en beroep hom op God se regverdigheid en die 
eer van sy Naam om die vyande uit te roei. In dieselfde asem bely hy egter dat hy nie onskuldig voor God is nie en vra hy dat God nie met hom 'n regsaak moet begin nie (Ps. 143:1-3, 9-12).

Die digter van Psalm 73 begin twyfel aan die goeie bestier van Jahwe en bejeën die hooghartige goddeloses met afguns oor hulle voorspoed. Maar dan kom hy tot inkeer oor sy gevoel van onreg. Om by God te wees, is meer werd as alles wat die hemel of die aarde kan bied. Die blywende verhouding met Hom strek oor die grense van hierdie bestaan (Oesterley,1959:91).

Gebed en woorde teenoor vyande word dus by die psalmdigters 'n belydenis van eie tekortkoming, van gebrek aan insig in God se werk. So staan Psalm 73 in die middel van die psalms, nie letterlik presies nie, maar wel teologies en kanonies (Brueggemann, 1991:81) as 'n baken, soos 'n hoë lamppaal wat die hele omgewing verlig. Dit wys dat die psalms gelees moet word met 'n korrektief op die digters se menslike benadering. Die digter kom tot hierdie insig wanneer hy na die heiligdom gaan, dit is in die besondere teenwoordigheid van God en die atmosfeer van die Tora.

Die psalms is verder 'n korrektief teenoor Israel se hele eie agtergrond en ondergrond (vgl. byvoorbeeld Ps. 95, 99, 106, 107, 108). Israel word gesien as 'n volk wat van sy voorouers af al 'n hardkoppige, uittartende en moedswillige volk is en nie God se paaie ken nie (Ps. 95:7-11; vgl. ook Ps. 106, 107). Hulle verdien eintlik nie om in die besondere verhouding van God en volk, of van Herder en kudde met die Here te wees nie.

Die psalmdigters se gebede teen die vyande word teen hierdie agtergrond gedoen. Diep binne is daar 'n besef van self skuldig en moedswillig te wees teenoor God. Al is daar min skuld- of boetepsalms (Ps. 6, 32, 38, 51, 102, 130, 143), ontbreek hierdie skuldbesef tog nie. Psalm 90 verbind trouens die mens se verganklikheid en sy sonde voor God en dui dit aan as wesenlike trekke van die mens (Ps. 90:3-10; vgl. ook Jes. 40:6-8 en verder Ps. 25:7, 11, 18; 40:13; 41:5; vgl. verder Helberg,1984:9 oor die besef van 'n diepe skuldbesef in Klaagliedere toe die vyand Jerusalem verower en verskrikking gesaai het).

Die tradisioneel hardkoppige en sondige gesindheid staan tussen Israel en die rus. (Vgl. ook Jes. 40:6-8 waarvolgens Israel deur die Woord van Jahwe vernietig word omdat hulle nie na die profete geluister het nie.) Hulle deel dieselfde gesindheidsagtergrond en -ondergrond as diegene wat hulle nie aan God se wil steur nie. 
Hulle het ook dieselfde mensheidsagtergrond, of -ondergrond (Gen. 1-11, veral 2, 3). As hulle dan deur God verkies word en tot 'n besondere lyn van Abraham behoort, dan maak Abraham se leuen aan die farao dit duidelik dat ook hý faal. Dit is alleen deur God se ontferming dat Hy die pad met Abraham en sy geslag nog verder loop en sodoende sy koninkryksheerskappy laat deurvoer.

Daar is dus ' $n$ voorlopigheid en, in hierdie sin, 'n beperktheid in die Ou Testament, maar tog bied dit self 'n korrektief. Selfs die psalmdigters benader hulleself korrektief, maar dit raak hulle eie skuld voor God. Hulle kom nie by die positiewe van die liefde vir die vyande nie, maar bly worstel met die kwessie van geregtigheid.

\section{Die verskil tussen die psalms, ook messiaanse psalms, en die benadering van Christus}

In Christus word die Wet/Woord mens (Joh. 1) en so word die spanning/botsing tussen die volk/die mens en God oorbrug (Jes. 40:6-8, 9-11). Die Wet bly nog voluit geldig (Matt. 5:17; vgl. ook Barnard, 2000:220, 221 oor die omvattende en totalitêre liefde en trou teenoor God in die psalms en wat geen neutraliteit teenoor die sonde en die onreg en die ongeloof verdra nie en wat maak dat ons geen deel van 'n psalm, byvoorbeeld 'n sogenaamde wraakgedeelte, mag uitlaat nie). Die Nuwe Testament gaan ook nie bokant die Wet uit nie.

Ridderbos $(1972: 271,277,280)$ sê tereg die vervulling van die Wet deur Jesus bestaan hierin dat $\mathrm{Hy}$ die liefdeskarakter van gehoorsaamheid wat deur die Wet vereis word, op 'n weergalose manier in die lig gestel het - bedoelende liefde in die sin van totalitêre, allesomvattende selfoorgawe. Die heil wat Jesus bring, tree nie in die plek van die Wet nie, maar dit plaas juis die van buite komende, geopenbaarde Wet op die enigste plek waar dit tot sy reg kan kom, naamlik in die hart van hulle wat Jesus aangeneem het. Tot sover Ridderbos. Psalm 1 sê reeds dat die heerskappy van die Wet/Woord nie 'n onpersoonlike, wettiese heerskappy is nie, maar 'n vreugdevolle omgaan (Ps. 1:2) met die wil van God, wat sy volk "ken", en persoonlik vir hulle sorg (Ps. 1:6).

Die verandering wat deur Jesus Christus gebring word, raak nie die wese van die Wet en sy eis nie, maar wel hoe die mens daarop as die persoonlike wil van God reageer. Die messias wat die regte reaksie by die mens kon teweegbring, is nie herkenbaar in die koningsgestalte wat byvoorbeeld in Psalm 2 (en ook Ps. 110) as koning geteken is nie. Vir die vervulling moes Christus ander 
gedagtelyne wat parallel met mekaar geloop het, uit die $\mathrm{Ou}$ Testament hiermee saam byeengebring. Die betekenis wat Christus met sy koms/vervulling teweeggebring het, kan dus nie teruggelees word na die Ou Testament of Ou-Testamentiese tyd nie. Die teks moet in sy verlenging op Christus toegepas word en nie bloot direk nie (Helberg, 1983:98). Die verlenging na Christus toe vra egter ook 'n kombinasie met ander tekeninge, wat alleen met Christus se vervullende koms kon gebeur.

Psalm 2 is dus wel messiaans en slaan op meer as net die gewone koning van Israel in daardie vroeë tyd, maar dit is nie messiaans in die sin dat dit Jesus Christus uitspel en dat dit verstaan kan word sonder die historiese gebeurtenis van Christus se koms in sy vervullende betekenis nie. Meijer (2002:9) se stelling dat Christus self sy psalms sing is dus té ongenuanseerd en simplisties en negeer die verskil wat in die benaming $\mathrm{Ou}$ en Nuwe Testament vervat is. Die aard van Jesus Christus se geboorte, soos deur Matteus gestel, bring na vore hoe die Ou-Testamentiese geskiedenis nie bloot soos 'n blomknop oopgegaan en in die Nuwe Testament/bedeling oorgegaan het nie.

Christus is nie 'n geëvolueerde produk van die Ou-Testamentiese geskiedenis nie. Hy veroorsaak self die verskil tussen die ou bedeling en die nuwe bedeling deurdat $\mathrm{Hy}$ verskillende gedagtelyne wat in die Ou Testament as 't ware ewewydig loop, eksistensieel en histories in Homself saamtrek. Met sy koms het Christus die geskiedenis op so 'n manier oopgebreek dat dit diskontinuïteit vertoon (vgl. byvoorbeeld Hebr. 3-8 oor die nuwe en beter bedeling). $\mathrm{Hy}$ is nie gebore uit 'n/die man, die draer van die beloftes en die messiaanse verwagtings nie, maar wel uit 'n vrou, deur die Heilige Gees (Matt. 1:18-25). Die geskiedenis het nie bloot ontvou nie. God het ' $n$ wondergeboorte laat plaasvind. So anders en nuut soos die geboorte, so nuut is die bedeling wat bewerkstellig word.

Christus maak daarop aanspraak om Koning en Priester te wees, iets wat geen koning in Israel was nie. Christus bring Psalm 110 tot vervulling, maar alleen Hy, met sy daadwerklike koms, kan die twee elemente bymekaar bring. Daarmee bring Hy tegelykertyd lig op die manier waarop Hy dit gaan doen: nie deur die lyding van ander, soos in Psalm 110 as deel van die ou bedeling gestel nie, maar deurdat Hy self daardie lyding sal ondergaan. So kry Psalm 110 eers deur dié vervulling wonderlike lig op die geheimnisvolheid van sy inhoud. 
Christus het gekom om in Homself die Messias se mag met selfverloënende liefde te verbind. Daarom vereis Hy radikale liefde van sy gelowiges - selfs om die vyand lief te hê (Matt. 5:43-48; Luk. 6:27-28, 32-36). Die gedeelte oor Christus, die Seun van Dawid (Ps. 110) volg nadat Christus se eis oor naasteliefde en vyandsliefde reeds deur Hom gestel is - 'n liefde wat nie in die psalms tot uitdrukking kom nie. In Matteus en Markus volg die gedeelte oor Christus die Seun van Dawid direk ná die gedeelte oor die groot gebod (Matt. 22:34-46; Mark. 12:28-37). In Lukas word die gedeelte oor die liefdesgebod nog veel vroeër geplaas (Luk. 10:2528).

Christus en sy koms as Messias is dus van ingrypende en verreikende betekenis. Dit hou in dat nie alleen enkele messiaanse tekste op Christus betrek moet word nie, maar ook al die psalms en al die ander Ou-Testamentiese gedeeltes. Die ander psalms mag nie gedegradeer word asof hulle nie ook op Christus betrekking het nie. Om die Ou-Testamentiese tekste op Christus te betrek kan nie in 'n gewone beryming of omdigting gedoen word nie. Die OuTestamentiese teks moet gehanteer word soos dit vir die OuTestamentiese bedeling gegeld het, nie soos dit deur Christus se koms vervul is nie. Christus het veral as 'n dienaar gekom en Hy stel daardie voorbeeld vir sy gelowiges om na te volg. Dit kom veral uit in sy dood. Hy sterf nie ter wille van Israel se nasionale verlossing nie, maar vir hulle verlossing van die sonde. Hy oorkom die onoorkomelike spanning tussen God en die Woord aan die een kant, en Israel sowel as die hele mensdom aan die ander kant (Jes. 40:6-8), deur die vervulling van die Wet en deur sy dood en opstanding. Om hieraan deel te hê moet 'n mens deel hê aan Christus.

Oorgawe aan die Woord (Ps. 1) wat die hele koningskap (Ps. 2) beheers, behels vir die gelowige 'n oorgawe aan (één wees met) hierdie dienende gestalte van Christus, die mensgeworde Woord. Met ander woorde, dit vereis liefde vir God en die naaste, en wel op so 'n radikale manier dat 'n mens selfs jou vyand liefhet, soos Christus sy vyande liefgehad het. Hy het ook ons, wat in der waarheid vyande van God is, kinders van God gemaak. Ons kan God nou aanspreek as Vader, iets wat nie in die Ou Testament gebeur het nie.

As kinders van God kan, wil en moet gelowiges ook hulle vyande liefhê. Die baie psalms waarin die psalmdigters hulle net op God se geregtigheid teen hulle vyande beroep en vra om vernietiging van die vyande, moet dus in 'n nuwe lig gelees en beleef word. Daarmee 
word nie 'n streep deur die psalmdigter se gemoedstemming oor die vyand en die verlange na geregtigheid getrek nie, maar die lyn word in die lig van Christus se ingrypende koms - sy reeds plaasgevonde sterwe en opstanding ter wille van sondaars, onder wie ook die bidder self - deurgetrek na 'n sterwens- en opstandingslewe en -gesindheid, wat 'n verlange na bekering vir die vyand insluit.

Christus stel die koninkryk radikaal in sy kern, die liefde. Hy stel ook vyandskap radikaal en betrek dit op die bose, wat nie net in ander volke of groepe of persone werksaam is nie, maar ook in elke mens se hart. Daarom leer $\mathrm{Hy}$ ons om te bid: "Vergewe ons ons oortredinge, soos ons ook dié vergewe wat teen ons oortree", en verder: "Laat ons nie in versoeking kom nie, maar verlos ons van die bose" (Matt. 6:13). Christus se vervulling van die messiaanse psalms hou dus nie alleen 'n nuwe benadering tot God se heerskappy in nie, maar bring ook 'n nuwe, radikale benadering tot vyandskap en vyande. Die bose word gesien as die vergestalting van vyandskap. Die bose moet beveg word, en sy verleiding moet vermy word, veral ook in ' $n$ mens se eie hart. Die vervulling behels nie dat net 'n enkele teks of tekste binne 'n bepaalde psalm betrekking op Christus het nie, maar veel meer: dit behels 'n nuwe, radikale verhouding met vyandskap en vyande en met die vyand der vyande, die bose. Dit behels dus 'n nuwe, radikale benadering van al die psalms.

Die mensgeworde Woord, Christus, het uit die dood opgestaan; dit is die Woord wat Hom so sterk met die mens vereenselwig dat $\mathrm{Hy}$ in 'n persoon gestalte aangeneem het en dat die mens se geskiedenis van ondergang en dood histories in Hom saamgetrek het. So het Hy deur sy opstanding uit die dood vir die mens 'n nuwe bedeling gebring. Die ou bedeling (Ou Testament) het daarmee ook in 'n sekere sin deur die dood gegaan. Ook die hoorder moet deur die dood gaan en (deur die Gees) as 'n nuwe mens opstaan, 'n ander gesindheid vertoon, soos om die vyand lief te hê.

Die psalms kan dus nie meer deur Christene gelees of gesing word soos in die Ou-Testamentiese tyd deur Israel, nog in 'n skadubedeling, wat liefde vir die vyand betref nie. Die NuweTestamentiese lig moet by die skaduagtige verkondiging van die psalms bygedink en geïnterpreteer word, nie net oor die persoon van Christus nie, maar ook oor die implikasies van sy koms, die eis om byvoorbeeld vyande lief te hê. 


\section{Samevatting en gevolgtrekking}

In die lig van Psalm 1 en 2, as inleiding tot die psalms, moet al die psalms messiaans benader word. Hulle stel meer in die vooruitsig as die werklikheid wat van God se regering deur sy gesalfde koning beleef word. Tog het die Ou-Testamentiese teks in die eerste plek op die koning of konings van Israel se tyd betrekking. Ook in sover die teks op iemand meer as die gewone koning betrekking het, gee dit slegs ' $n$ beeld van die messias as magtige koning wat met uiterlike mag sy vyande oorwin. Met die vervulling is Hy, Christus, veel meer 'n dienende kneg of slaaf. Die redding wat Hy uiteindelik bewerkstellig, word deur die Nuwe Testament as redding deur "die onsin van die kruis" beskryf. Die houding teenoor die vyand wat Hy van sy gelowiges eis, is om hulle lief te hê, anders as die oorheersende houding van die psalmdigters. Hulle eis geregtigheid in die vorm van straf en vernietiging vir die vyande. Dat straf ook vir Christus nie uitgesluit word nie, is duidelik uit sy uitsprake oor die oordeel wat vir die Fariseërs en Skrifgeleerdes wag en oor die oordeel in sy profetiese redes (Matt. 24, 25). Nou is egter die interimtyd voordat $\mathrm{Hy}$ weer kom. Die klem lê nou op liefde en bekering (Helberg, 1983:101; Barnard, 200:220-221).

Vervulling in Christus gebeur nie sonder die ingrypende implikasies van sy vervullende koms nie. Daar kom 'n nuwe verbond waarin God self sy Wet/Woord in mense se harte inskryf en daarmee ook 'n innerlike oorwinning oor die vyande - deur liefde - bewerkstellig.

'n Hoofletterskryfwyse vir die messias in die psalms laat nie die implikasies van sy vervulling vir die res van die betrokke psalm, en wat nie met die gebruik van hoofletters en kleinletters of ander soort letters aangedui kan word, uitkom nie. So word daar bo-oor die ingrypende, radikale verandering en vervulling wat Christus nog eers daadwerklik, histories moes bewerkstellig, en wat saamtrek in sy dood en opstanding, gespring en word nie nuwe lig gewerp op die vereiste verhouding teenoor vyande nie, maar word dit onveranderd gelaat. Sodoende word daardie houding wat nog tot die skadubedeling behoort, eerder gesanksioneer asof dit nou ook 'n Nuwe-Testamentiese benadering is - dit wil sê dié van Christus.

Psalm 2 en die ander psalms kan dus messiaans in NuweTestamentiese sin gelees word, maar die implikasie van die koms van Christus moet in Nuwe-Testamentiese lig bygedink en die psalm daarvolgens geïnterpreteer word. Vertaling en omdigting van die psalms kan dit nie uitdruk nie en daar moet by die OuTestamentiese teks gehou word. Die ingrypende betekenis van die 
vervulling deur Christus kan nie uitgedruk word deur bloot die messias met 'n hoofletter aan te dui nie.

\section{Geraadpleegde bronne}

BALLARD, H.W., Jr. 1999. The divine warrior motif in the Psalms. North Richland Hills: Bibal Press.

BARNARD, A.C. 2000. Die besondere betekenis van die Psalms in die Christelike kerk. Skrif en Kerk, 21(2):214-227.

BRIGHT, J. 1967. The authority of the Old Testament. London: SCM.

BRUEGGEMANN, W. 1991. Bounded by obedience and praise: the Psalms as canon. Journal for the study of the Old Testament, 50:63-92.

CHILDS, B.S. 1979. Introduction to the Old Testament as Scripture. London: SCM.

CHILDS, B.S. 1986. Old Testament theology in a canonical context. Philadelphia: Fortress.

D'ASSONVILLE, V.E. 2002a. Die nuwe Psalmberyming 2001: weglatings en afwykings van die Hebreeuse teks. Waarheid \& Dwaling, 8(2):4-6.

D'ASSONVILLE, V.E. 2002b. Skrifgesag - Christus - die Psalmberyming 2001. Waarheid \& Dwaling, (8)5:3-6.

D'ASSONVILLE, V.E. 2004. Die stryd rondom die suiwer psalmboek: Stellenbosch 1812 - Rustenburg - Potchefstroom 2003. Die Kerkpad, 8(1):10, 11, 27.

D'ASSONVILLE, V.E., jnr., KAYAYAN, E. \& SCHULZE, L.F. 2004. Christus self is in gedrang. Die Kerkblad, 106(3161):32-33.

DAVIS, B.C. 2000. Is Psalm 110 a Messianic psalm? Bibliotheca Sacra, 157:160-173.

GEMSER, B. 1949. De Psalmen 111. Groningen: Wolters. (Tekst en Uitleg.)

GERSTENBERGER, E.S. 2002. Theologies in the Old Testament. London: Clark.

HELBERG, J.L. s.a. The Lord reigns: revelation history of the Old Testament. Potchefstroom: PU for CHE.

HELBERG, J.L. 1983. Verklaring en prediking van die Ou Testament. Potchefstroom: Potchefstroomse Teologies Publikasies.

HELBERG, J.L. 1984. Klaagliedere: ontnugtering en hoop. Potchefstroom: Potchefstroomse Teologies Publikasies.

HELBERG, J.L. 2005. Geïntegreerdheid van die psalms volgens die verband tussen Psalm 1 (en 2) en die res van die psalms. In die Skriflig, 39(4):673694.

KRATZ, R.G. 1996. Die Tora Davids. Zeitschrift für Theologie und Kirche, 93:134.

KRAUS, H-J., 1972. Psalmen. 1. Neukirchen-Vluyn: Neukirchener Verlag. (Biblischer Kommentar, 15/1.)

McCANN, J.C. 1993. Books I-III and the editorial purpose of the Psalter. (In McCANN, J.C., ed. The shape and shaping of the Psalter. Sheffield: JSOT Press. JSOT Supplement Series, 159:93-107.)

MEIJER, J.G. 2002. Mag gereformeerde kerke die nuwe psalmberyming aanvaar? Waarheid \& Dwaling, 8(2):7-10.

MITCHELL, D.C. 1997. The message of the Psalter: an eschatological programme in the Book of Psalms. JSOT Supplement Series, 252. 
OESTERLEY, W.O.E. 1959. The Psalms. London: SPCK.

PAUL, M.J. 1987. The order of Melchizedek (Ps. 110:4 and Heb. 7:3). Westminster Theological Journal, 49:195-211.

PREUSS, H.D. 1996. Old Testament theology, 11. Louisville: Westminster John Knox.

RIDDERBOS, H.N. 1955. De Psalmen. Kampen: Kok. (Commentaar op het Oude Testament.)

RIDDERBOS, H.N. 1972. De komst van het koninkrijk. Kampen: Kok.

SHEPPARD, G.T. 1991. "Enemies" and the politics of prayer in the book of Psalms. (In Jobling, D., Day, Peggy L., Sheppard, G.T., eds. The Bible and the politics of exegesis. Essays in Honour of Norman K. Gottwald on his sixty-fifth birhday. Cleveland: Pilgrim Press. p. 61-82.)

SNYMAN, S.D. 2002a. Die verstaan en funksie van die Ou Testament in die kerk; of, Kan die kerk sonder die Ou Testament klaarkom? Deel 1. Acta Theologica, 22(2):126-146.

SNYMAN, S.D. 2002b. Die verstaan en funksie van die Ou Testament in die kerk; of, Kan die kerk sonder die Ou Testament klaarkom? Deel 2. Acta Theologica, 22(2):147-162.

TOOMBS, L.E. 1971. The Psalms. (In Laymon, M., ed. 1971. The Interpreter's one-volume commentary on the Bible. London: Collins. p. 253-303.)

VAN ROOY, H.F. 2004. Die nuwe Psalmomdigting: die messias weggelaat? Hervormde Teologiese Studies, 60(3):755-767.

VAN ROOY, H.F. 2005. Messiasverwagting en prediking uit die Ou Testament. In die Skriflig, 39(3):615-630.

VERHOEF, P.A. 2004. Die 2001-Psalmomdigting: word die Messias "wegvertaal"? Die Kerkblad, 106(3161):36-37, 39.

VRIEZEN, Th. C. 1966. Hoofdlijnen der theologie van het Oude Testament. Wageningen: Veenman.

WEISER, A. 1959. Die Psalmen. Göttingen: Vandenhoeck \& Ruprecht. (Das Alte Testament Deutsch, 14/15.)

WILSON, G.H. 1992. The shape of the Psalms. Interpretation, 46:129-142.

ZENGER, E. 2000. Psalmenforschung nach Hermann Gunkel und Sigmund Mowinckel. (In Lemaire, A. \& Saebo, M., eds. Congress volume, Oslo, 1998. Brill: Leiden. p. 399-435.) (Supplements to Vetus Testamentum, 80.)

\section{Kernbegrippe:}

messiaans

psalms

Psalm 1 en 2

vyand

\section{Key concepts:}

\section{enemy}

messianic

psalms

Psalms 1 and 2 